\title{
Social gains from the public relations voice of activist investors: The case of Herbalife and Pershing Square Capital Management
}

\section{Introduction}

This intention of this article is to investigate the purpose, practice and outcome of the financial public relations (PR) voice of activist investors. The inquiry is framed in the terms of Hirschman's (1970) variation on classical economics, the theoretical continuum of exit, voice and loyalty. In considering outcomes, the point of interest was whether a PR campaign undertaken primarily for private financial reward could additionally generate the social gains associated with conventional activism or corporate social responsibility (CSR). An investigation into the specifics of the public relations of activist investors is timely because of the worldwide growth of investor activism. In particular, Europe has been described recently as a potential "new hunting ground for bloodthirsty activists" from the USA (Fortado, 2016).

Beyond the niche of activist investment - and despite the growth of finance and its significance in economic, political and societal terms - public relations and investor relations (IR) work in the financial sector has not attracted significant research attention with Doan and McKie's (2017, p.306) 22-year literature review from 1994 to 2016 yielding just 56 articles in communications journals and 97 in business journals on these themes. In opening remarks to her book on PR in financial markets, Bourne (2017, p. ix) reflected upon the "astonishingly scant number of books or articles published on public relations in finance" going on to opine that "the majority of PR scholarship ignores finance altogether" with the result that PR has ceded ground to other disciplines such as economics, linguistics, management science and journalism.

Laskin (2014a, p. 127) had earlier posited that this dispersal of knowledge across diverse disciplines had epistemological consequences in the form of a "certain disconnect between publications that makes it hard to develop a unified body of knowledge" in IR and financial PR. Kelly, Laskin and Rosenstein (2010, p. 182) uncovered a epistemological disconnect in the form of the "unfortunate" paradox of investor relations receiving "little attention in public relations scholarship, even though the discipline claims investor relations as one of its specializations, or subfunctions" while at the same time "investor relations practice has grown in importance and received increased attention in corporate America".

This article is offered to help address the research deficit on financial PR, consider PR's role in investor activism and to add to PR literature more generally with its application of the well-tested economic theoretical frame of exit, voice loyalty to analyse the activist voice of public relations campaigning. In addressing these aims, the author is mindful of Laskin's (2014a) concerns over disciplinary dispersal of knowledge along with Doan and McKie's (2017, p. 306) call for researchers to "develop "synergies from their existing differences" and so reaches widely to the fields of corporate governance, economics and finance, as well as public relations to offer the interdisciplinary consideration of the IR practice of activist investors that follows. 


\section{Literature review}

Financialization and Financial Public Relations

Financialization has been defined by Marazzi (2011, p. 26) as pervasiveness of the financial economy in society "that spreads across the entire economic cycle" funding cars, consumer goods and so on in a way that makes the financial services sector "cosubstantial" with production. The economic effects of financialization are associated with extremes of expansion and contraction in capital markets such as, for example, the growth in the types of financial instruments and increased trading volumes leading up to the 2008 financial crash, which saw a 100-fold growth of credit derivatives in ten years with over $\$ 47 \mathrm{bn}$ USD of credit default swaps alone outstanding in 2008 (Harrington \& Moses, 2008). More recently, the rapid growth of car loans under the guise of personal contract purchase plans has led to $85 \%$ of new cars being bought using dealer finance (more than double the figure in 2009), raising fears among regulators that auto lending could be driving the next financial crisis (Dunkley \& Arnold, 2017).

Financialization has not been much addressed in public relations and media literatures with a search of the Journal of Public Relations Research and Public Relations Review yielding only nine articles that addressed investor relations topics relating to financial markets. The majority of this work addressed corporate IR and offered overviews of the field (see, for example Laskin, 2006; Laskin, 2011; O’Byrne \& Daymon, 2014; Laskin, 2014b) rather than the subset of the financial markets IR undertaken by institutional investors or fund managers with their investors. Kelly, Laskin and Rosentein (2010, p. 182) made a theoretically important advance by linking IR to prevailing PR theory by testing adoption of the Grunigian two-way symmetrical model by IR practitioners. They went on to assert that as the first study to find "the predominant practice of the normative model" it refuted longstanding criticism of the symmetrical model as a utopian ideal. (Grunig \& Hunt, 1984) concluding that it was widely used in the "bastion of capitalism - publicly owned corporations in the United States". This conclusion mirrored IABC Excellence study's (Grunig, 1992) corporate focus on building relationships with investors through relational investing in order to encourage long term holding of the stock (Lowenstein, 1996).

Coupled with the absolute growth of the financial sector, concerns over credibility and trust in financial markets (Bourne, 2017, p. 1) have driven demand for public relations services in the field, with over $20 \%$ of PR workers now employed in some area of finance and $26 \%$ of agency staff reporting finance as the client sector they are most likely to represent (CIPR, 2015). When investor relations and public relations in financial markets have been addressed the topic is often discussed alongside fields of concern to PR scholars (see Uysal, 2014, for example), including CSR, socially responsible investing (SRI), organizational legitimacy and shareholder activism. Moreover, such discussions are predominantly oriented from a corporate and financial perspective, reflecting perhaps the reality of IR practice as "most frequently treated as a financial function, both in terms of who is in charge, and what are qualifications for the job" because CEOs "do not perceive investor relations to be part of the public relations function” (Petersen \& Martin, 1996, p. 204).

\section{Activism}

Shareholder activism is the process by which shareholders seek to influence corporate actions in their favour rather than the interests of the "corpocracy" of managers who promote their own interests (Monks, 2008). Specifically, activism is the exercising of influence and statutory rights in the form of "actions taken by shareholders with the explicit intention of influencing corporations' policies and practices" (Goranova \& Ryan, 2014, p. 1232). One lawyer who researched investor 
activism through a study of media coverage of 432 campaigns over ten years (Katelouzou, 2013) opined that "the brand of shareholder activism associated with hedge funds is a highly topical, yet equally controversial issue" in which many aspects "are unresolved or have become popularized notions about which little is still known." The tactics of some early specialist activist investment funds - such as the break-up of businesses, selling of assets and cutting jobs - have long been criticised for putting short-term rewards ahead of the long-term health of companies, perhaps most famously in the acquisition of RJR Nabisco by activist investors KKR of New York in 1988 who were recorded in book and cinema format as The Barbarians at the Gate (Burrough \& Helyar, 1989). Since then, activist investment become popular among hedge funds as a strategy for extracting value by forcing changes such as disposals with the sector experiencing a "resurgence" in 2017 (Fortado, 2017) as "activist investors flush with cash hunt for returns outside the US" (Daneshkhu, Fortado \& Nicolau, 2017). The public relations campaign tactics used by activist investors involve engagement with the press, often through the publication of letters to the board of management of companies that lead in turn to investor pressure for change, such as the June 2017 letter to the board of Nestle from the US activist Dan Loeb of Third Point of New York, which included specific targets for improvement such as " a formal margin target, more share buybacks and sale of Nestle's stake in French cosmetics giant, L'Oreal" (Chaudhuri \& Backstone, 2017; Third Point LLC, 2017).

The underlying orthodoxy of PR activism literature is that PR can contribute to social change by helping to solve enduring problems through its benign influence and many book titles share a sense of reinvention of the discipline to serve these ends: It's not just PR: Public Relations in Society (Coombs and Holladay, 2007); Reconfiguring Public Relations (McKie \& Munshi, 2007); Public Relations Activism and Social Change (Demetrious, 2013), Public Relations As Activism (Holtzhausen, 2013). In these and other texts, public relations on behalf of activist interests in the social sphere has been largely positioned as positive but it can arguably also be harmful to wider society as a result of the tyranny of minority effect in which a small number of activists secure change that favours their interests (Thompson, 2016), often due to effective vocalization of those interests in their campaigning.

\section{Hirschman's Theorem of Exit, Voice and Loyalty}

Albert Hirschman's book Exit, Voice and Loyalty: Responses to decline in firms, organizations and states was first published in 1970 (Hirschman, 1970) and his consideration of the interaction of these factors went on to have "enormous impact throughout and beyond the social sciences" (Bootsma, 2013, p. 111). When he died in 2012, an obituary in The Economist lamented Hirschman not being awarded "the Nobel prize in economics he so richly deserved, perhaps because his writing was hard to classify" in its spanning of so many fields (Schumpeter, 2012). Classical economics theorized consumers facing the option of either buying or not buying when confronted by suppliers of poor quality goods or services, with the "invisible hand" of the market (Smith, 2005) re-ordering supply and demand as a result. The theory of exit, voice and loyalty offers a third option of voice in the cases of repairable lapses, which is exercised either as a residual of exit in cases when exit is not possible (often for reasons of geography or limited supply) or as an alternative to it (Hirschman, 1970, p. 33).

In cases of "discontented member customers", Hirschman defined voice as both "any attempt to change rather than to escape from an objectionable state of affairs, through individual or collective petition .... Or through various types of actions and protests, including those meant to mobilize public opinion" in a process of "interest articulation" (Hirschman, 1970, p. 31). In considering the 
case of institutional investment and in particular "active shareholders", McNulty and Nordberg (2015, p. 353) categorized the exercise of voice as one of the processes of shareholder action affecting governance in their model of active ownership, in which voice functioned as an either private or "public-formal" form of "overt challenge" in the quest for change. Ragas (2018, p. 187) added more detail to this "challenge" dimension of voice with an explication of the vocalisation of positions in contested takeover attempts or proxy contests, having earlier laid out a role for the voice of Hirschman's continuum as a tool in "political-style strategic communications campaigns" in which different sides of the takeover battle "try and convince shareholders to support their candidate(s) for the board" (Ragas \& Culp, 2014, p. 100).Research aim

Following on from the successful application of the exit, voice, loyalty theorem to the communications aspects of activist investment by McNulty and Nordberg (2015) and Ragas (2018) - which built upon earlier work in the same vein (Lodgson \& Van Buren, 2009; Rehbein, Logsdon \& van Buren, 2013; Goodman, Louche, van Cranenburgh \& Arenas, 2014) - Hirschman's construct is used here as a theoretical framework to consider the social gains resulting from a single case of investor activism. Specifically, the aim of the research summarised here was to investigate the purpose, practice and outcome of the public relations "voice" of an activist investor in the case of Pershing Square and Herbalife from 2012-2018.

\section{Methodology}

"Rich, detailed case studies" have been recommended as an important empirical contribution to understanding the work of individual and organizational actors in affecting institutions (Lawrence, Suddaby \& Leca, 2009, p. 2). Motivated by the call for empirical studies, this inquiry sought to investigate the activist voice of the Pershing Square hedge fund during the period of its investment position in Herbalife (which was first disclosed in late 2012) and also the effects of its activist voice in connection with this position. The object of analysis was the organizational discourse of Pershing Square, with a particular focus on the financial public relations campaign outputs that vocalized its concerns and diffused them into the financial markets during the period of its investment position in Herbalife between 2012 and 2018. An organization's discourse is said to consist of "structured collections of texts and writing (as well as a wide variety of visual representations and cultural artefacts)" and the way they are produced, disseminated and consumed (Grant, Hardy, Oswick \& Putnam, 2004, p. 3). This means a set of texts can be considered both as a manifestation of discourse and a "discursive unit" in itself (Chalaby, 1996). The texts scrutinized in this investigation included the financial public relations and investor relations outputs of Pershing Square between 2012-2017 (including annual presentations to investors and research reports), transcripts of investor conference calls, relevant regulatory filings to the Securities and Exchange Commission (SEC) and press coverage relating to Pershing Square's short position in Herbalife, including television interviews with Bill Ackman, founder and chief executive officer (CEO) of Pershing Square and documentary films of the episode.

In this way, the methodology combined analysis of the institutional work of the Pershing Square founder alongside semiotic, rhetorical and narrative analysis of the textual outputs used to solicit support (Coreen, 2015, p. 59). Institutional work was considered here because of its communicative dimensions, including advocacy, definition, constructing identities, constructing normative networks and mimicry, as defined by Lawrence and Suddaby (2006, p. 221). These communicative forms of institutional work were considered alongside narratives using the research method deployed by Zilber (2009, p. 205) in an empirical case study that investigated the bidirectional "travel of institutional stories across social levels" and diffusion of "societal meta- 
narratives into organisations". This analysis of narrative as a form of institutional work at the heart of organizational discourse was operationalized through a combination of discursive institutionalist methodology (Atkinson, 2008, p. 361) and narrative analysis of the investor relations discourse with the capital markets. This type of multi-levelled and multi-sourced approach to researching organizational discourse has been advocated by Broadfoot, Deetz and Anderson (2004, p. 194) who encouraged investigators to build a multi-dimensioned "complex and vivid picture of discourse and organizing life" through focus on the "techniques and vocabularies" deployed to generate discursive formations - in this case the communicative enactment of the activist voice of Pershing Square.

\section{Findings}

Purpose

On 19 December 2012, Bill Ackman, CEO of the \$11bn USD assets under management (AUM) Pershing Square hedge fund confirmed to Reuters that he had committed around \$1bn USD to a short position in health products company, Herbalife, resulting in a $12 \%$ decline in the share price, making it the day's biggest faller on the New York Stock Exchange (Herbst-Baylis, 2012). Herbalife describes itself as a "global nutrition company that has helped people achieve healthy, active lives since 1980" (Herbalife, 2017). In fillings to the Securities and Exchange Commission (SEC) Herbalife explained that it markets its products through a network of "independent distributors" because of a belief that "the direct-selling channel is ideally suited to marketing our products because sales of weight management, nutrition and personal care products are strengthened by ongoing personal contact, coaching and education between distributors and their customers" while in the same document acknowledging that challenges to the legality of its "network marketing program" represent a risk to the company (Herbalife, 2013, p. 4-5).

Pershing Square used the investment strategy of short selling - effectively a bet that the Herbalife stock price will go down - by borrowing shares from a stock lender (typically a fund administrator and custody bank) and selling them on the open market, with the intention of returning the borrowed shares to the lender at some point in the future after the stock price has fallen. This type of investment exposure means that any holder of a short position hopes for the target firm's share price to go down and so short sellers are incentivized to expose problems in public companies in order to initiate or accelerate share price decline. In Hirschman's terms, short selling goes beyond exit and becomes the inverse of the loyalty displayed by a long term holder (a class of investor that is largely silent) with a corresponding vocalisation of discontent with the company. Ackman himself was clear on this investment aim, explaining simply: "Herbalife stock goes down, we make money; Herbalife stock goes up, we lose money" (Adair, Zipper \& Braun, 2017). There was also a social dimension to the short position for Ackman, who claimed that short selling in companies that Pershing Square has identified are "doing harm" provides a rare opportunity to make large profits for investors in the fund while also "providing a public service" (Adair et al. 2017). In interviews, Ackman repeated his claim of social purpose, "moral crusade" ("Herbalife: The House of Cards Put," 2014) and even patriotism, saying that "this is going to sound goofy but we try to do things that we think are good for America" (Delventhal, 2017).

The purpose of Pershing Square's campaigning in support of its investment position was to drive down the share price of Herbalife, ideally to catastrophically low levels or even force bankruptcy. This purpose was pursued by vocalising - through public relations, lobbying and other channels the concern that Herbalife was operating a fraudulent pyramid scheme. Pershing Square's goal was 
to introduce information to the marketplace that would undermine the value of Herbalife through negative investor sentiment and regulatory action against the alleged pyramid scheme. Pershing Square was supported by two public relations firms, the New York-based communications and reputation management firm Rubenstein and Global Strategy Group (GSG). GSG, a public affairs firm, was hired to co-ordinate state-level lobbying and campaigning on behalf of Pershing Square throughout the USA. In addition, John Silvan, CEO of GSG served as personal adviser to Ackman at investor presentations and guided the follow-up media relations strategy. The prestigious New York law firm Sullivan and Cromwell, described by Ackman himself as "one of the best law firms in the country" (CNBC, 2015) was retained by Pershing Square to produce due diligence documents on Herbalife. The aim of this work was to trigger investigations by Federal and State regulators into Herbalife's business practices, the findings of which would ideally lead to the company being shut down due to illegal trading activities. In retaining Sullivan and Cromwell, Ackman's purpose appears to have been to increase credibility for his investment arguments through deploying supportive legal opinions and due diligence reports from a respected law firm. In terms of spending, Ackman confirmed in interviews that legal fees were the largest item of expenditure followed by research and the costs of the "advocacy" work of the PR campaign to spread the message (CNBC, 2015).

In addition to generating and distributing third party research and legal opinion on Herbalife to the media, regulators and lawmakers, Pershing Square reached out to the Latino community in order to recruit disgruntled Herbalife distributors who had lost money. This community outreach work included helping Latino leaders form anti-Herbalife activist groups of their own to lobby state consumer protection and attorney general's offices, as well as bundling up their stories "to present to Congress" ("Herbalife: The House of Cards Put", 2014) or lobby the Federal Trade Commission (FTC) for redress. The FTC's statutory role of "protecting America's consumers" includes investigating and preventing unfair or deceptive selling. Pershing Square regarded "regulatory investigations and public scrutiny" as central to its investment strategy of achieving "deterioration of the business and earnings" of Herbalife (Pershing Square, 2015, p. 31). The main purpose of its varied activist campaign of media relations, lobbying of political representatives and support of Latino activists was to trigger such an inquiry into Herbalife.

Practice

In a letter to investors dated 13 March 2015, Bill Ackman provided an inventory of the mix of communications Pershing Square had deployed in the first two years of its campaign against Herbalife:

We have publicly issued numerous presentations, white papers and analyses which are available on the www.factsaboutherbalife.com and www.herbalifepyramidscheme.com websites. Video and audio recordings of our public presentations are available on these websites. (Ackman, 2015).

Pershing Square opened its campaign on 20 December, 2012, at the AXA Equitable Center, in Manhattan with a presentation to investors, journalists and financial analysts called "Who wants to be a Millionaire?', a proposition that was apparently intended also to capture the attention of regulators, politicians interested in consumer rights, the mainstream media, and Spanish-language news outlets that could cover the story in the Latino community. The emphasis in the early stages was on informational campaign inputs in the form of extensive white papers and analysts' reports 
on aspects of Herbalife's operations, with Ackman recalling "we did a huge amount of research and that is costly - there were 330 slides in our first deck" (CNBC, 2015).

After the initial presentation, a series of detailed dossiers were produced and published. In some cases, the material was the result of Pershing Square's own research effort, in others the documents were the work of law firms or research houses retained by Pershing Square. One such was Christine Richards, an independent researcher running her own firm, Orion Research, who was contracted to work full time on Herbalife projects by Pershing Square. In a sign of the intensity of the information-based campaign, OTG Research Group of Clearwater Florida was accused by a lawyer acting for Herbalife of "improper conduct". In a warning letter to OTG Research Group, the New York lawyers Gibson, Dunn and Crutcher accused the firm of "contacting current and former Herbalife employees and offering to compensate them in return for confidential, proprietary and privileged information belonging to Herbalife" (Goldsmith, 2015).

Dossiers generated by different researchers were issued over the campaign and seem to have been timed strategically to depress the share price around quarterly earnings statements by Herbalife. For example, Pershing Square made a presentation and issued a 63-page report on Herbalife's operations in China with support from OTG Research Group on 11 March 2014 (Pershing Square, 2014a), just one week after Herbalife announced its fourth quarter (Q4) earnings for 2013. On 22 July 2014, one week ahead of Herbalife's Q2 results announcement, Pershing Square hosted another presentation jointly with Christine Richards at which it published a 239-page report entitled The Big Lie on Herbalife's use of "nutrition clubs", which the report claimed were an a exploitative distribution channel that targeted specific ethnicities (such as Latinos in the USA), vulnerable groups and "the extremely poor in new and existing markets" in order to sell around $40 \%$ of its total sales volume (Pershing Square, 2014b). In addition to live presentations to media, analysts and investors, each report was the focus of a media relations outreach and was also made available online along with video of the presentations on one of several anti-Herbalife campaign websites set up by Pershing Square.

At the local level, Pershing Square engaged with state Attorney Generals and Senators offering case studies of Herbalife distributors who had lost money and these individuals also made complaints of their own. According to one report, "Pershing Square spent hundreds of thousands of dollars lobbying state senators" and members of Congress as well as meeting with the Securities and Exchange Commission (S.E.C.), activists in the Latino community and reportedly made donations to Latino "civil-rights groups to help find victims of Herbalife whom they could present to regulatory agencies, making videos of their stories and posting them online" (Kolhatkar, 2017). Ackman's engagement with activist groups became more intense and personal over time and by March 2014 he talked of a "moral crusade against Herbalife" and "promised to give away his personal profits from the trade to charity", including a fund he set up to aid the Latino community and other undocumented immigrants ("Herbalife: The House of Cards Put", p.73).

\section{Outcome}

This activist campaign practices of Pershing Square yielded the first political results in early 2014, when on 23 January, the Democratic Senator Edward Markey of Massachusetts, a member of the Commerce, Science and Transportation Committee, called on the F.T.C. and S.E.C. "for more information about the business practices of Herbalife" after hearing "serious complaints of improper pressure and financial hardship, including from a constituent in Massachusetts who lost her entire retirement savings" (Markey, 2014a). In his letter to the FTC chair, Senator Markey, who 
positions himself as a consumer champion, called on the Commission to "investigate the company's business practices yourself to confirm that the company is acting in accordance with the consumer protection laws" and is not making "false and deceptive claims about either the efficacy of Herbalife's products or the business opportunities available to Herbalife distributors" (Markey, 2014b). The day after Senator Markey called for a FTC probe, anti-Herbalife "activists met with California's Attorney General's Office to discuss Herbalife" (Pershing Square, 2015). The FTC's decision to begin a civil investigation into Herbalife was made public on 12 March 2014 and on 11 April 2014, this was followed by reports of an inquiry into possible criminal wrongdoing by the Department of Justice and Federal Bureau of Investigation (F.B.I.) which "raised the stakes for Herbalife, which is already facing civil inquiries from multiple government agencies that are looking into the Los Angeles-based company and its associated network of independent distributors" (McCrum \& Scannell, 2014). Later in 2014, probes were announced by Attorney Generals in Illinois and New York, confirming the successful momentum of the campaign (Pershing Square, 2015).

In July 2016, with its investigation complete, the FTC issued a "stinging rebuke" of Herbalife's business practices as a California Court levied a $\$ 200 \mathrm{~m}$ USD settlement to be paid to distributors who lost money in a judgment the regulator claimed would "transform the way Herbalife does business" (Foley, 2016). The court documents for the settlement were damning and concluded that "the Defendants' program does not offer participants a viable retail-based business opportunity" and that promotional material in English and Spanish contained "misleading income representations" (United States District Court, District of California, 2015). Despite the damning indictment of Herbalife, the shares rallied as investors expressed relief that the judgement was not harsher and as the prospect of Herbalife being shut down entirely as a result of regulatory pressure diminished. Stock market support for Herbalife meant there were buyers for the stock and also an investment counter-narrative to Pershing Square's negative campaigning. The result, according to the Financial Times was a "social gain without monetary ones" as Ackman's activist campaign while not a financial success for his fund - led to regulatory intervention that forced Herbalife to change its business practices (Lex, 2016). On 28 February 2018, the five year battle - described in a Bloomberg report as "one of the longest and most colourful battles in Wall street history" - was over, as Ackman exited his positions with Herbalife shares up almost 100\% since he announced his interest in the company in December 2012 (Deveau, 2018).

Throughout the campaign, Herbalife was retaliating at Pershing Square's assault on the company, spending seven times Pershing Square's declared federal lobbying budget in 2013 ("Herbalife: The House of Cards Put", 2014). In July 2014, Herbalife announced the appointment of Alan Hoffman as Executive Vice President of Global Corporate Affairs (Herbalife 2014) Hoffman was wellconnected in Washington and had served as Deputy Assistant to US President Barrack Obama and Deputy Chief of Staff to US Vice President Joe Biden. His appointment - at a total compensation package of $\$ 2.4 \mathrm{~m}$ USD for 2014 (salary.com, 2015) heralded the start of a sophisticated fightback against Ackman's activist campaigning. In July 2016, after Herbalife settled with the Federal Trade Commission following the investigation it had launched in 2014, Hoffman used a clever statement consisting of just two sentences to present what was in effect a $\$ 200 \mathrm{~m}$ USD fine for wrongdoing and a lost court case as the outcome of two year process of co-operation with the FTC:

After more than two years of working with the FTC, I think we understand the terms of the settlement agreement very well. We would not have settled unless we had the greatest 
confidence in our ability to comply with the agreement and grow our business and we believe this will be proven out over time. (Herbalife, 2016).

\section{Discussion}

Although Pershing Square was not a shareholder during the time of its short position - it had already exited in Hirschman's terms - it retained an investment interest (as a short seller and holder of options) in the Herbalife share price declining and so used voice in support of its position to expose the company's shortcomings. This application of an activist voice by Pershing Square is logical from economic, communicative and campaigning perspectives. Ackman's short position meant he was interested in the failure of Herbalife - or as large a decline as possible in its share price - so had a huge incentive to publicise wrongdoing, which he pursued through engagement with financial media and the stock market using financial public relations and lobbying. In considering the public relations campaigning aspects using the terms and theoretical frame of Hirschman's exit, voice, loyalty continuum, the Pershing Square/Herbalife case is notable for the intensity of the voice dimension. The activist public relations voice in this case included a high investment in research in order to generate information assets such as investigative reports into Herbalife's business practices. This one-way distribution of information places the IR and financial PR enacted by Pershing Square and its advisers as predominantly in the public information category of Grunig and Hunt's (1984) four typologies of PR. Despite widespread use of research (often the basis for Grunigian two-way communication) there is little evidence of attempts at any form of symmetrical or two-way communication in this case, with research information used instead to establish a stronger position and support for one-way public argumentation as a tool of persuasion, rather than to better understand audience or stakeholder concerns.

The potential of supra-normal financial rewards of investor activism gives incentives for deep levels of research in order to uncover information helpful to an investment position and then publicise the findings through information-based public relations campaigning in order to move the share price. In contrast, the budget for the Attorney General's office and the New York State Legal Department's 1,700 staff - including 650 assistant attorneys - is $\$ 215 \mathrm{~m}$ USD for its five divisions, one of which is the Economic Justice division (New York State Office of Attorney General, 2017). Assuming an equal division among the five divisions gives the Economic Justice team - in which the Bureau of Consumer Frauds \& Protection is based - a budget for all casework of just over $\$ 40 \mathrm{~m}$.USD In contrast, Ackman spent around $\$ 50 \mathrm{~m}$ USD on investigating and publicising the single case of Herbalife, resulting in more intense information gathering that had previously been achieved by the market, the media, the public and the regulator combined. It was this level of investment and informational intensity that led to social gains as the regulator would not have had grounds to mount an investigation into Herbalife's business practices without the extensive dossiers gathered on Herbalife by Ackman. Yet despite his vocalising of his activist concerns, Ackman's option lost around half a billion US dollars although, according to one report, "his relentlessness performed a public service" in exposing the flaws in Herbalife's business and generating better terms for those who work part-time selling the products (Lex, 2016). The FTC's statement on conclusion of the case echoed Ackman's own claim that Herbalife was doing harm in its explication of the $\$ 200 \mathrm{~m}$ USD settlement levied by the court for "consumers we contend were harmed by the practices challenged in the Commission's complaint" while pointing to a wider gain on consumer protection in the form of "important reminders to other multi-level marketing companies $[\ldots]$ to ensure their practices are not unfair, false or misleading”(FTC, 2016). 
Two aspects of Pershing Square's public relations practice deserve particular consideration: the use of research/dossier-based campaigning in enacting a voice that supports the financial interests of the short position (or inverted investment loyalty); and the duality of its activist campaign work in the way it addressed wider social issues to a broader audience as well as narrow investor concerns. Although it is common practice in issues-based campaigning to deploy research and third party endorsements, the sheer volume, scope and depth of information in this case was unusual. Moreover, the campaign was not built around one report but rather a series of detailed dossiers from various third parties on different aspects of Herbalife's operations that were issued at intervals over the course of the campaign. Ackman himself repeatedly stressed the dimensions involved in this work, whether it was the number of pages (330 for the first December 2012 presentation in New York), the time spent by Pershing Square (50 people for 18 months), the budget (around $\$ 50 \mathrm{~m}$ USD) or the range and calibre of advisers involved (New York law firms, several research specialists). This explanatory effort appeared to be aimed at building credibility based on the time and cost of preparing the dossiers as information assets and campaign artefacts as much as their contents. It also appeared to be building depth to the campaign voice as well as defining the tone of voice as solid, dependable and well-grounded in extensive research.

In this way, Ackman was using the same dossier-based public information campaigning as had been used, for example by the UK and US governments in 2003 as they made the case to go to war in Iraq. In the case of the UK, Prime Minister Tony Blair published a summary of intelligence assessments in what became known as a "dodgy dossier" entitled Iraq - Its Infrastructure of Concealment, Deception and Intimidation, which was issued to journalists on 3 February 2003 by Alistair Campbell, Blair's director of communications and strategy. In the USA, on 5 February 2003, US Secretary of State, Colin Powell, gave a briefing speech to the United Nations Security Council supported by a visual dossier of intelligence information (United Nations, 2003). In both cases, dossiers were used as a tool of public information to support a position. In considering their consumption by audiences, the pattern was similar to the Ackman case in that few citizens beyond interested specialists would read the material in full if at all. Instead, the length of the dossier coupled with authoritative presentation built credibility for the general argument and in some cases, the visual artefact of a picture of the cover with details on pagination in a positive news report would be enough to settle the matter for the majority of media audiences. More recently, the carefully-curated January 2017 publication of the 35-page Donald Trump-Russia dossier provided a contemporary example of the impact of dossier-based public information campaigning, in this case, apparently by a coalition of anti-Trump Republican and Democratic supporters (Buncombe \& Garcia, 2017).

In adopting activist public relations campaign techniques in order to enact and project its investor voice in financial markets, Pershing Square shrewdly aligned its investment priorities with wider public interest concerns relating to multi-level marketing and the harmful economic and social effects such practices had on aspiring Latino immigrants in the United States, as well as other groups who were vulnerable to financial exploitation such as recently retired or redundant workers. Pershing Square's campaigning was based on research into Herbalife's operations that alleged the multi-level sales practices made its financial model unsustainable and that the company was a pyramid scheme that preyed on vulnerable people. At the same time as making this case to financial markets, media, political representatives and regulators in traditional PR outreach, Pershing Square engaged with activists in the Latino community through the local, campaigning work co-ordinated by Global Strategy Group. This aspect of Pershing Square's campaign resembled a conventional, social activism in the way it involved public meetings, protests at 
Herbalife conventions and other grassroots campaigning by disaffected distributors who had formed groups to confront Herbalife with their own activist movement.

\section{Conclusion}

The case of Pershing Square and Herbalife suggests that Hirschman's exit-voice-loyalty continuum offers a useful economically-based theoretical frame for investigating the purpose, practice and effects of public relations of activist investors, including the question whether this type of PR can result in social gains. Beyond the specifics of activist campaigning in financial markets, the findings from this exploratory project suggest there is potential for wider application of Hirschman's ideas in public relations research. The close fit of Hirschman's theoretical frame to the example discussed here suggests a case for more detailed development of the theorization of public relations as a process that enables the formulation and distribution of client voice, for example. In this theorization, public relations is not only a tool of communication, but also at the centre of the process of confrontation of poor quality or poor performance that involves the exercise of voice. Such a theorization implies that the purpose, practices and effects of public relations can be considered beyond campaigning as an enabler and enhancer of efficacy of the voice option. In this way, the public relations voice has both political and economic effects in the case of campaigning undertaken on behalf of a client or principal that elects to vocalise concerns rather than pursuing the exit or loyalty options. In relation to existing PR theory, the voice of activist investor as observed in this single IR case study was firmly in the one-way communication category of public information as defined by Grunig and Hunt (1984) in their work on excellence and symmetric communication. This finding contradicts the assertion by Kelly, Laskin and Rosenstein (2010, p. 204) following their study based on a survey of practitioners, which concluded that IR professionals did predominantly use the two-way symmetrical model.

Beyond finance, crisis management scenarios involving third parties - such as the recent example of corporations in the entertainment sector distancing themselves from celebrities against whom allegations of sexual misconduct, for example - could be informed by the application of Hirschman's theoretical construct of exit, voice and loyalty. Similarly, in the field of celebrity endorsement, deciding when to align with charitable causes and when to withdraw support when the charity is in trouble is another possible application. These types of decisions present precisely the varied options beyond the binary choices of exit or loyalty that Hirschman modelled. For example, the decision by the actress Minnie Driver to resign as a celebrity patron of Oxfam following the 2018 revelation of aid workers using prostitutes while working in Haiti after the 2010 earthquake was criticised by some journalists and commentators as "virtue signalling" and pandering to the media at time when the charity needed support (Cooper, 2018). The Hirschman continuum offers not only a theoretical framework for understanding the forces involved in such situations but also a practical roadmap for decision making based on economic value as to whether to stay loyal to a troubled party, to exit any association or to vocalise concerns.

The generic theorization of public relations as the enactment of Hirschman's voice construct proposed here, along with the specifics of financial public relations on behalf of activist investors, both require testing and refinement, ideally through empirical work. The arguments offered here are derived from a single example and so should be treated with the caution appropriate for such an exploratory study. Another limitation on validity is that the Pershing Square/Herbalife case featured a fund manager whose activist purpose was to achieve a share price decline through confrontation of Herbalife's business practices. Comparative case studies of activist public relations campaigns by shareholders who exercise voice in support of a company (that is they are 
both loyal and vocal) are needed to test the wider applicability of the theoretical framing of public relations as the exercise of the activist voice. In considering instances of short-selling activist funds and conventional shareholder activism, more detailed inquiries at both empirical and theoretical levels into the formulation of public relations practice as a process that gives economic and political voice to activist concerns would be welcome. Finally, the social gain Pershing Square delivered in the Herbalife case in the form of regulatory intervention by the FTC is an example of activist PR campaigning achieving a social gain, although it was achieved not directly but via regulatory intervention ordering change in business practice. On first viewing, it appears that this type of activist public relations campaigning can play a role in generating benefits to society in ways associated with both corporate social responsibility and social activism, despite the purpose at the outset being economic gain. However, this assertion requires more reflection, ideally in a separate study framed within the existing literature on CSR and using modes of investigation suited to considering CSR and PR themes in the same project. 


\section{References}

Ackman, W. (2015). Pershing Square Responds to The Wall Street Journal Herbalife Article. Letter to investors dated 13 March. Retrieved from http://www.businesswire.com/news/home/20150313005522/en/Pershing-Square-RespondsWall-Street-Journal-Herbalife

Adair, D., Zipper, G. (Producers) and Braun, T (Director). (2017). Betting on Zero. United States, Biltmore Films.

Atkinson, T. (2008). Textual mapping of imitation and intertextuality in college and university mission statements: A new institutional perspective. Semiotica 172 (1), 361-387.

Bootsma, B (2013). An Eclectic Approach to Loyalty-Promoting Instruments in Corporate Law: Revisiting Hirschman's Model of Exit, Voice, and Loyalty. Erasmus Law Review, 6 (2), 111130.

Bourne, C. (2017). Trust, power and public relations in financial markets. London: Routledge.

Broadfoot, K. Deetz, S. and Anderson, D. (2004). Multi-levelled, Multimethod Approaches to Organizational Discourse. In D. Grant, C. Hardy, C. Oswick \& L. Puttnam (Eds.), The Sage Handbook of Organisational Discourse (pp. 105-128). London: Sage.

Buncombe. A. and Garcia, F. (2017, February 10). Donald Trump Russia dossier: US intelligence confirms truth of some details. The Independent. Retrieved from http://www.independent.co.uk/news/world/americas/donald-trump-russia-dossiera7574536.html

Burrough, B. and Helyar, J. (1989). Barbarians at the Game: The Fall of RJR Nabisco. New York: Harper and Row.

Chalaby, J. (1996). Beyond the prison-house of language: Discourse as a sociological concept. British Journal of Sociology 47(4), 684-698.

Chaudhuri, S. and Blackstone, B. (2017, June 28). Nestle Hurries to Score Points. Wall Street Journal Europe, p. B1.

CIPR (Chartered Institute of Public Relations), 2015. State of the PR Profession Research Report. London: Chartered Institute of Public Relations

CNBC (2015, March 13). Scott Wapner interview with Bill Ackman. Retrieved from https://www.cnbc.com/video/2015/03/13/bill-ackman-herbalifes-a-criminal-enterprise.html

Coombs, T. and Holladay, S. (2007). It's not just PR: public relations and society. Oxford, UK: Blackwell.

Cooper, K. (2018, February 15). Cause celeb': the uncomfortable truth about charity ambassadors.

The Telegraph. Retrieved from http://www.telegraph.co.uk/women/life/cause-celebuncomfortable-truth-charity-ambassadors/

Cooren, F. (2015). Organizational Discourse. Cambridge: Polity 
Daneshkhu, S., Fortado, L. and Nicolau, A. (2017, July 21). Consumer goods make appetising target for US activists. Financial Times. Retrieved from https://www.ft.com/content/176507c8-6d53-11e7-bfeb-33fe0c5b7eaa

Delventhal, S. (2017, June 8). William Ackman's Crusade to Take Down Herbalife. Investopedia. Retrieved from http://www.investopedia.com/articles/investing/022817/william-ackmanscrusade-take-down-herbalife.asp\#ixzz4jyBwPvx5

Demetrious, K. (2013). Public Relations, Activism, and Social Change: Speaking Up. New York: Taylor \& Francis.

Deveau, S. (2018). Bill Ackman Gives Up Herbalife Fight, Ending Five-Year Saga. Bloomberg (28 February). Retrieved from https://www.bloomberg.com/news/articles/2018-02-28/ackman-issaid-to-cede-herbalife-fight-ending-five-year-saga

Doan, M. and McKie, D. (2017). Financial investigations: Auditing research accounts of communication in business, investor relations, and public relations (1994-2016). Public Relations Review 43 (2) 306-313.

Dunkley, E. and Arnold, M. (2017, July 9). Warning signs emerge in the UK car loan market. Financial Times. Retrieved from https://www.ft.com/content/8b6607de-6304-11e7-91a7$502 f 7 e e 26895$

Federal Trade Commission, (2016, July 15). Statement of the Federal Trade Commission FTC v. Herbalife International of America, Inc. Retrieved from https://www.ftc.gov/system/files/documents/public_statements/971213/160715herbalifestate ment.pdf

Foley, S. (2016, July 15). Bill Ackman's bet sours as Herbalife settles with FTC. Financial Times. Retrieved from https://www.ft.com/content/9c3ae610-4a8c-11e6-8d68-72e9211e86ab

Fortado, L (2016, May 23). Homegrown activism takes root in Europe. Financial Times. Retrieved from https://www.ft.com/content/1e7c55f2-20ce-11e6-aa98-db1e01fabc0c

Fortado, L. (2017, July 1). Revival of a master of the universe. Financial Times, p. 9.

Goldsmith, B. (2015, December 8). Letter to Aaron Smith-Levin of OTG Research Group. Retrieved from https://stoptheamwaytoolscam.files.wordpress.com/2013/02/2015-12-08-lettergasparino.pdf

Goodman, J., Louche, C., van Cranenburgh, K. C., and Arenas, D. (2014). Social Shareholder Engagement: The Dynamics of Voice and Exit. Journal of Business Ethics, 125(2), 193-210.

Goranova, M. \& Ryan, L. (2014). Shareholder Activism: A Multidisciplinary Review. Journal of Management, 40, 130-1268.

Grant, D., Hardy, C. Oswick, C. and Putnam, L. (2004). The Sage Handbook of Organizational Discourse. London: Sage.

Grunig, J. (1992). Communication, public relations, and effective organizations: An overview of the book. In J. E. Grunig (Ed.), Excellence in public relations and communication management (pp. 1-28). Hillsdale, NJ: Lawrence Erlbaum Associates. 
Grunig, J. and Hunt, T. (1984). Managing Public Relations. New York: Holt, Rinehart \& Winston.

Harrington, S. and Moses, A. (2008, November 6). Credit Swap Disclosure Obscures True Financial Risk. Bloomberg News. Retrieved from www.bloomberg.com

Herbalife, (2013, February 19). Form 10-K: Annual Report Pursuant to Section 13 or 15(D) of The Securities Exchange Act of 1934 for the fiscal year ended December 31, 2012. United States Securities and Exchange Commission, Washington. Retrieved from https://www.sec.gov/Archives/edgar/data/1180262/000119312513065327/d452887d10k.htm \#toc

Herbalife (2014, July 25). Herbalife appoints Alan Hoffman Executive Vice President of Global Corporate Affairs. Retrieved from http://ir.herbalife.com/releasedetail.cfm?ReleaseID=862107

Herbalife, (2016, July 20). Herbalife Issues Statement. Business Wire. Retrieved from http://ir.herbalife.com/releasedetail.cfm?ReleaseID=980388

Herbalife (2017). Our History. Retrieved from http://company.herbalife.com/our-history

Herbalife: The House of Cards Put. (2014, March 15). The Economist, p. 73.

Herbst-Bayliss, S. (2012, December 20). Pershing Square's Ackman shorts Herbalife; stock skids. Reuters. Retrieved from http://www.reuters.com/article/us-ackman-herbalife-idUSBRE8BI1 MZ20121220

Hirschman, A. (1970). Exit, Voice and Loyalty. Cambridge, Mass. Harvard University Press.

Holtzhausen, D. (2013). Public Relations as Activism: Postmodern Approaches to Theory and Practice. United States: Routledge.

Katelouzou, D. (2013). Myths and Realities of Hedge Fund Activism: Some Empirical Evidence. Virginia Law \& Business Review 7, 459-511. Retrieved from https://ssrn.com/abstract=2152351

Kelly, K. Laskin, A. and Rosenstein, G. (2010). Investor Relations: Two-way Symmetrical Practice. Journal of Public Relations Research 22 (2) 182-208.

Kolhatkar, S (2017, March 6). Financiers Fight Over the American Dream. The New Yorker. Retrieved from http://www.newyorker.com/magazine/2017/03/06/financiers-fight-over-theamerican-dream

Laskin, A. (2006). Investor relations practices at Fortune 500 companies: An exploratory study. Public Relations Review 32 (1) 69-70.

Laskin, A. (2011). How Investor Relations Contributes to the Corporate Bottom Line. Journal of Public Relations Research, 23,(3) 302-324.

Laskin, A. (2014a). Investor Relations as a Public Relations Function: A State of the Profession in the United States. Journal of Public Relations Research 26 (3) 200-214.

Laskin, A. (2014b). Strategic Financial Communication. International Journal of Strategic Communication, 8 (3), 127-129. 
Lawrence, T. and Suddaby, R. (2006). Institutions and institutional work. In S. Clegg, C. Hardy, W. Nord and T. Lawrence (Eds.) Handbook of Organization Studies (pp. 215-254). Thousand Oaks, CA: Sage.

Lawrence, T., Suddaby, R. and Leca, B. (2009). Introduction: theorizing and studying institutional work. In T Lawrence. R, Suddaby \& B. Leca (Eds.) Institutional Work: Actors and Agency in Institutional Studies of Organizations (pp. 1-28). Cambridge: Cambridge University of Press.

Lex (2016, July 15). Herbalife/Ackman: shake it off: Social gains without monetary ones. Financial Times. Retrieved from https://www.ft.com/content/0bb7a1a6-4aa4-11e6-b38764ab0a67014c

Logsdon, J. M., and Van Buren, H. J. (2009). Beyond the proxy vote: Dialogues between shareholder activists and corporations. Journal of Business Ethics, 87, 353-365.

Lowenstein, L. (1996). Relational Investing. New York: Oxford University Press

Marazzi C. (2011). The Violence of Financial Capitalism. Los Angeles, CA: Semiotext(e).

Markey, E. (2014a). Markey Calls for Investigation into Herbalife Business Practices.[Press release] 23 January. Retrieved from https://www.markey.senate.gov/news/press-releases/markeycalls-for-investigation-into-herbalife-business-practices

Markey, E. (2014b). Letter from Senator Edward Markey to The Honourable Edith Ramirez, 23 January. Retrieved from https://www.markey.senate.gov/imo/media/doc/2014-1-22_Ramirez_Herbalife.pdf

McCrum, D. and Foley, S. (2014. March 15). US wades into Herbalife dust-up. Financial Times, p. 17.

McCrum, D. and Scannel, K. (2014, April 11). Criminal probe launched into Herbalife. Financial Times. Retrieved from https://www.ft.com/content/a9833e96-c198-11e3-b95f-00144feabdc0

McKie, D. and Munshi, D. (2007). Reconfiguring Public Relations: Ecology, Equity and Enterprise. New York: Taylor \& Francis.

McNulty, T., and Nordberg, D. (2016). Ownership, Activism and Engagement: Institutional Investors as Active Owners. Corporate Governance , 24(3), 346-358.

Monks, R. (2008). Corpocracy. Hoboken, N.J.: John Wiley \& Sons.

New York State Office of Attorney General (2017). Our Office. Retrieved from https://ag.ny.gov/our-office

O'Bryne, S. and Daymon, C. (2014). Irresponsible Engagement and the Citizen Investor. Journal of Public Relations Research 26 (5) 455-473. 
Pershing Square Capital Management L.P., (2014a). Herbalife in China, 3 March presentation. Retrieved from http://assets.factsaboutherbalife.com/content/uploads/2015/08/13220453/HerbalifeInChina.pd $\mathrm{f}$

Pershing Square Capital Management L.P., (2014b). The Big Lie, 22 July presentation. Retrieved from http://assets.factsaboutherbalife.com/content/uploads/2016/01/24052648/Nutrition_Club_Pre sentation_The_Big_Lie_7.22.14.pdf

Pershing Square Capital Management L. P. (2015). Annual Update Presentation, 29 January. Retrieved from https://www.pershingsquareholdings.com/media/2014/09/2014-PSH-AnnualUpdate-Presentation.pdf

Petersen, B. \& Martin, H. (2009). CEO Perceptions of Investor Relations as a Public Relations Function: An Exploratory Study. Journal of Public Relations Research 8 (3) 173-209. Ragas, M. \& Culp, R. (2014). Business essentials for strategic communicators: Creating shared value for the organization and its stakeholders. New York: Palgrave Macmillan.

Ragas, M (2018). Corporate proxy contests: Overview, application and outlook. In A. Laskin (Ed.), The Handbook of financial communication and investor relations (pp. 187-196). New York: Wiley.

Rehbein, K., Logsdon, J., and van Buren, H. (2013). Corporate Responses to Shareholder Activists: Considering the Dialogue Alternative. Journal of Business Ethics, 112(1), 137-154.

Salary.com (2015). Alan L. Hoffman: Executive Compensation. Retrieved from http://www1.salary.com/Alan-L-Hoffman-Salary-Bonus-Stock-Options-for-HERBALIFELTD.html

Schumpeter (2012, December 22). Exit Albert Hirschman. The Economist. Retrieved from https://www.economist.com/news/business/21568708-great-lateral-thinker-died-december10th-exit-albert-hirschman

Smith, A. (2005). The Wealth of Nations. New York: Everyman's Library/Random House.

Third Point LLC (2017). Investor letter dated 25 June. Retrieved from http://www.thirdpointpublic.com/wp-content/uploads/2017/06/Third-Point-Nestle-Letter.pdf

Thompson, G. (2016). Towards a theory of rent-seeking in activist public relations. Public Relations Inquiry 5 (3) 23-231.

Uysal, N. (2014). The Expanded Role of Investor Relations: Socially Responsible Investing, Shareholder Activism, and Organizational Legitimacy. International Journal of Strategic Communication, 8(3), 215-230.

United Nations (2003). Briefing Security Council, US Secretary of State Powell Presents Evidence of Iraq's Failure to Disarm. SC/7658, 4701 ${ }^{\text {st }}$ meeting, 5 February. New York. Retrieved from http://www.un.org/press/en/2003/sc7658.doc.htm

United States District Court District of California (2015). Complaint for injunction and further Equitable Relief. Case No. 2:16-cv-05217: Federal Trade Commission versus Herbalife 
International of America Inc., 15 July. Retrieved from

https://www.ftc.gov/system/files/documents/cases/160715herbalifecmpt.pdf

Zilber, T. (2009). Institutional Maintenance as Narrative Acts. In T. Lawrence, R. Suddaby, B. Leca (Eds.) Institutional Work: Actors and Agency in Institutional Studies (pp. 205-235).

Cambridge: Cambridge University Press. 